(c) 2010 IEEE. Personal use of this material is permitted. Permission from IEEE must be obtained for all other uses, in any current or future media, including reprinting/republishing this material for advertising or promotional purposes, creating new collective works, for resale or redistribution to servers or lists, or reuse of any copyrighted component of this work in other works. 


\section{Criteria for hardware selection of Wireless Vibration Sensor}

\author{
Mohammad reza Akhondi, Alex Talevski \\ DEBII \\ Curtin University of Technology, \\ Perth, Western \\ AustraliaM.Akhondi@postgrad.curtin.edu.au \\ A.Talevski@curtin.edu.au
}

\author{
Tsung-Hsien Chou \\ Curtin University of Technology \\ Perth, Western Australia \\ chou1332@hotmail.com
}

\begin{abstract}
Vibration Sensor Hardware has three sub-fields as accelerometer, microcontroller and wireless device. This paper is dedicated to deliver more detail information on individual hardware and list of criteria for hardware selection in Wireless Vibration Sensors.
\end{abstract}

Keywords-component; accelerometer; microcontroller; wireless device; individual hardware

\section{INTRODUCTION}

The hardware field for the sensor will obviously be similar to Figure 1. There are 3 major components. End Device (ED) is the actual sensor. The sensor also has multiple limitations bounded to its design. They are listed below.

- Sensor output must be digital

- Sensor must be modular with parts on-board

- Sensor wireless communication in radio frequency

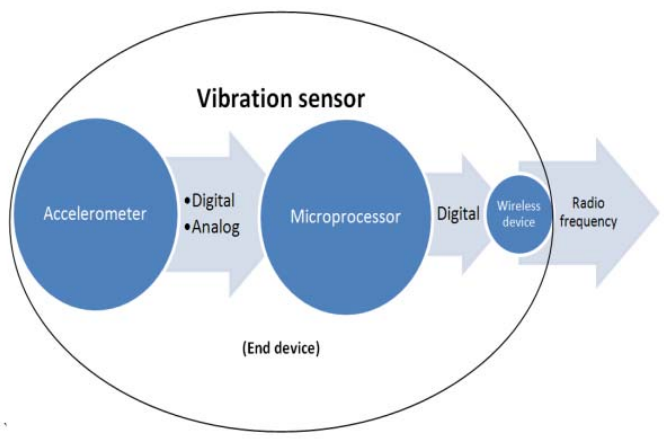

Figure1. Schematic diagram of end device

\section{ACCELEROMETER}

The SmartVib has few concerns in circuit complexity, hardware compatibility and signal transmission. Ordinary accelerometer requires external circuit to perform the data transmission and manipulation. Nowadays, advance technology has improved electronic component manufacturing. Particularly, MEMs technology is one of many techniques that integrate the capability of accelerometers and bring the hardware configuration into nano technology.

Fundamentally, there is one thing needs to be clarify is the measurement unit. It is extremely significant in conversion from one quantity to another, especially for measurement instrument. Accelerometer has two types of expression in its unit of measurement. There are milllivolt per $\mathrm{g}(\mathrm{mV} / \mathrm{g})$ and picoCoulombs per $\mathrm{g}(\rho \mathrm{C} / \mathrm{g})(33)$. It means every millivolt or picocoulombs change in the voltage reading there is a $1 \mathrm{~g}$ $(9.81 \mathrm{~m} / \mathrm{s} 2)$ change in acceleration of the object being sensed [1].

According to ENDEVCO [1], it indicates a few types of accelerometer such as Piezoelectric (PE), Piezoresistive (PR), Variable Capacitance (VC), Force-Balance Servo (SERVO), Thermal Zero Shift (TZS) and Transducer Electronic Data Sheet (TEDS). Texas Instrument adds more types of accelerometer including Hall effect, magnetoresistive and heat transfer. The table of characteristic of each type accelerometer illustrates in the Appendices part A for design reference purpose.

According to above core selection criteria, the manufacture reduced down to three major brands. The table below indicates the detail further.

TABLE I. AVAILABLE ACCELEROMETER BASED ON REQUIREMENT

\begin{tabular}{|c|c|c|c|c|c|c|}
\hline \multicolumn{7}{|c|}{ Analog Device } \\
\hline Model & Axis & Range & Output & $\begin{array}{c}\text { Sensitivity } \\
(\mathrm{mg} / \mathrm{LSB})\end{array}$ & $\begin{array}{c}\text { Bit } \\
\text { revolution }\end{array}$ & $\begin{array}{c}\text { Availab } \\
\text { ility }\end{array}$ \\
\hline ADXL345 & 3 & $\pm 16 \mathrm{~g}$ & $\begin{array}{c}\mathrm{I}^{2} \mathrm{C}, \\
\mathrm{SPI}\end{array}$ & $29 \sim 36$ & 10 & $\begin{array}{c}\text { After } \\
\text { April, } \\
2010\end{array}$ \\
\hline ADXL346 & 3 & $\pm 16 \mathrm{~g}$ & $\begin{array}{c}\mathrm{I}^{2} \mathrm{C}, \\
\text { SPI }\end{array}$ & $29 \sim 35$ & 10 & $\begin{array}{c}\text { After } \\
\text { April, } \\
2010\end{array}$ \\
\hline ADIS16240 & 3 & $\pm 19 \mathrm{~g}$ & SPI & $\begin{array}{c}\text { X=17.125, } \\
\text { Y=8.407 }\end{array}$ & 10 & Active \\
\hline \multicolumn{7}{|c|}{ STMicroelectronics } \\
\hline Model & Axis & Range & Output & $\begin{array}{c}\text { Sensitivity } \\
(\mathrm{mg} / \mathrm{LSB})\end{array}$ & $\begin{array}{c}\text { Bit } \\
\text { revolution }\end{array}$ & $\begin{array}{c}\text { Availab } \\
\text { ility }\end{array}$ \\
\hline LIS331HH & 3 & $\pm 24 \mathrm{~g}$ & $\begin{array}{c}\mathrm{I}^{2} \mathrm{C}, \\
\text { SPI }\end{array}$ & 12 & 12 & Active \\
\hline \multicolumn{7}{|c|}{ BOSCH } \\
\hline Model & Axis & Range & Output & $\begin{array}{c}\text { Sensitivity } \\
\text { (mg/LSB })\end{array}$ & $\begin{array}{c}\text { Bit } \\
\text { revolution }\end{array}$ & $\begin{array}{c}\text { Availab } \\
\text { ility }\end{array}$ \\
\hline BMA220 & 3 & $\pm 16 \mathrm{~g}$ & $\begin{array}{c}\mathrm{I}^{2} \mathrm{C}, \\
\text { SPI }\end{array}$ & 500 & 6 & Active \\
\hline BMA120 & 3 & $\pm 16 \mathrm{~g}$ & $\begin{array}{c}\mathrm{I}^{2} \mathrm{C}, \\
\text { SPI }\end{array}$ & 500 & 6 & Active \\
\hline
\end{tabular}

Clearly, Table I indicates there three major differences between each model. These are sensitivity, bit revolution and availability. In particular, model LIS331HH has the highest sensitivity in three axes with highest bit revolution. The availability status of this model is also active. Model LIS331HH seems a good options from this three factors. Following section gives a more detail comparison to ensure the accelerometer option. 


\section{A. Selection criteria}

There are many selection criteria from different aspect of view; Table II shows the final version of selection criteria in descending order. Since there is no standard for accelerometer selection the table can be used as a guide to select a proper accelerometer for general application. For instance, the typical application is criticizing automobile, electric motor, vibration mechanism, hardware monitoring etc.

TABLEII. CREATED ACCELEROMETER SELECTION CRITERIA.

\begin{tabular}{|c|c|}
\hline Order & Criteria \\
\hline 1 & Analog/Digital \\
\hline 2 & Number of axis \\
\hline 3 & $\begin{array}{c}\text { Type of } \\
\text { measurement }\end{array}$ \\
\hline 4 & Type of technology \\
\hline 5 & $\begin{array}{c}\text { Measurement range } \\
\text { and Sensitivity }\end{array}$ \\
\hline 6 & Frequency range \\
\hline 7 & Bandwidth \\
\hline 8 & Impedance/Buffering \\
\hline 9 & Voltage supply \\
\hline 10 & Temperature range \\
\hline 11 & Linearity \\
\hline 12 & Communication port \\
\hline 13 & Reliability \\
\hline 14 & Cost \\
\hline 15 & Size \\
\hline & \\
\hline
\end{tabular}

\section{1) Criterion1: Analog/Digital}

Analog/Digital criterion is placed in first because it will determine some other criterion. For example, designer select digital option and the criterion 9 can be ignored as it applies to analog accelerometer. Another reason is the available option on the market is divided into half and this means designer is half way closer to the expecting accelerometer. According to research and organizing of varies selection method, the most common criterion come across (in first hand) is to choose either analog or digital accelerometer. This is actually dependent on design's preference. As previous section 1.2 mentions few drawbacks of analog device and it gives encouragement for designer to create a new digitized sensor. Besides, Eren states that digital signal has the following advance feature as immune to noise, reduced error correction and, encryption and security can be easily addressed. Thus, digital based accelerometer tends to be a better option for the purposed sensor [2].

\section{2) Criterion 2: Number of axis}

The second criterion has divided the total half into three portions. Thus designer is closer to the proper selection of accelerometer. The number of axis detection is dependent on the measurement application. It is not necessary to purchase a tri-axis accelerometer. Single axis accelerometer can be combined to form the same application as tri-axis.
The WiVi sensor is tends to have three axes vibration detection.

\section{3) Criterion 3: Type of measurement}

Criterion three guides designer to define the type of measurement for application. Bruce (S.W.P 33) states that type of measurement has divided into four major categories. There are vibration, shock motion and seismic. Obviously, the WiVi new sensor fits into vibration category [3].

\section{4) Criterion 4: Type of technology}

It indicates there are PE, IEPE, PR, VC.SERVO, TZS, TEDS etc, it gives advantage and disadvantage of each type of accelerometer and includes the desire applications.

\section{5) Criterion 5: Measurement range and Sensitivity}

According to WEG paper, the general electric motor has vibration amplitude from 1.8 to $4.5 \mathrm{~mm} / \mathrm{s}$. However, the WiVi sensor is tended to have a slightly wider measurement range.

Another consistency criterion is the sensitivity. Sensitivity shows the accuracy of device. For example, $1000 \mathrm{mV} / \mathrm{g}$ gives the every $1000 \mathrm{mV}$ change in the voltage reading there is a $1 \mathrm{~g}$ change in the acceleration of object being sensed (arabrise.org). The higher sensitivity the better is in accuracy.

In compare the measurement range from table 3, STMicroelectronics seems to have the highest measurement range $\pm 24 \mathrm{~g}$ with high sensitivity $12(\mathrm{mg} / \mathrm{LSB})$ in measurement.

\section{6) Criterion 6: Frequency range}

Toliyat indicates the frequency range is between $10 \mathrm{~Hz}$ and $1000 \mathrm{~Hz}$ [4]. Frequency range illustrates the capability of amplitude that accelerometer can still function probably during measurement period. If the frequency range of mechanism hardware is an unknown value, following table gives a recommended frequency spans for reference in some general cases [5].

Designer tends to select wide frequency range as much as possible from three particular manufactures. Refers to the data sheet that provides in appendices part $\mathrm{F}$, the following table can be built.

TABLE III. TABLE OF FREQUENCY RANGE COMPARISON

\begin{tabular}{|l|l|c|}
\hline \multicolumn{1}{|c|}{ Manufactures } & \multicolumn{1}{|c|}{ Model } & \multicolumn{1}{c|}{$\begin{array}{c}\text { Frequency } \\
\text { range }\end{array}$} \\
\hline \multirow{3}{*}{ Analog Device } & ADXL345/346 & $\begin{array}{c}6.25 \mathrm{~Hz} \sim \\
3200 \mathrm{~Hz}\end{array}$ \\
\cline { 2 - 3 } & ADIS16204 & $360 \mathrm{~Hz} \sim 440 \mathrm{~Hz}$ \\
\hline STMicroelectronics & LIS331HH & $0.5 \mathrm{~Hz} \sim 1000 \mathrm{~Hz}$ \\
\hline \multirow{2}{*}{ BOSCH } & BMA120 & $50 \mathrm{~Hz} \sim 1000 \mathrm{~Hz}$ \\
\cline { 2 - 3 } & BMA220 & $32 \mathrm{~Hz} \sim 1000 \mathrm{~Hz}$ \\
\hline
\end{tabular}

Based on the result of comparison from table III, the ADXL345/346 has the most wide frequency range than others. Unfortunately, table 3 indicates the availability status is after April 2010, thus the best option is the LIS331HH 
accelerometer from STMicroelectronics. The frequency range is from $0.5 \mathrm{~Hz}$ to $1000 \mathrm{~Hz}$ and it has sufficient margin for hardware health monitoring system.

\section{7) Criterion 7: Bandwidth}

Bandwidth is the frequency difference between high-pass filter (HPF) cutoff frequency and low-pass filter (LPF) cutoff frequency. It gives the amount of time per second that device can take a reliable acceleration reading. Ignored ADXL345/346 due to availability status, the following table gives the comparison result of bandwidth from each accelerometer.

TABLE IV. TABLE OF BANDWIDTH COMPARISON

\begin{tabular}{|c|c|c|c|c|}
\hline Manufactures & Model & \multicolumn{3}{|c|}{ Bandwidth } \\
\hline Analog Device & ADIS16204 & \multicolumn{3}{|c|}{$360 \mathrm{~Hz} \sim 440 \mathrm{~Hz}$} \\
\hline \multirow{5}{*}{ STMicroelectronics } & \multirow[t]{5}{*}{ LIS331HH } & ODR & $\begin{array}{c}\text { HPF } \\
\text { cutoff } \\
\text { Frequency } \\
(\mathrm{Hz})\end{array}$ & $\begin{array}{c}\text { LPF } \\
\text { cutoff } \\
\text { Frequency } \\
(\mathrm{Hz})\end{array}$ \\
\hline & & 50 & $\begin{array}{c}1,0.5 \\
0.25 \\
0.125\end{array}$ & 37 \\
\hline & & 100 & $\begin{array}{c}2,1,0.5 \\
0.25\end{array}$ & 74 \\
\hline & & 400 & $8,4,2,1$ & 292 \\
\hline & & 1000 & $\begin{array}{c}20,10,5 \\
2.5\end{array}$ & 780 \\
\hline \multirow{2}{*}{$\mathrm{BOSCH}$} & BMA120 & \multicolumn{3}{|c|}{$\begin{array}{c}50 \mathrm{~Hz}, 75 \mathrm{~Hz}, 150 \mathrm{~Hz}, 250 \mathrm{~Hz}, \\
600 \mathrm{~Hz}, 1 \mathrm{kHz}\end{array}$} \\
\hline & BMA220 & \multicolumn{3}{|c|}{$32 \mathrm{~Hz} \sim 1000 \mathrm{~Hz}$} \\
\hline
\end{tabular}

Table IV indicates the LIS331HH has adjustable bandwidth according to ODR and HPF cutoff frequency. Compare to others, LIS331HH accelerometer has higher flexibility in bandwidth scale. The scale has lower level bandwidth range from $0.125 \mathrm{~Hz}$ to $37 \mathrm{~Hz}$ and upper level bandwidth range from $20 \mathrm{~Hz}$ to $780 \mathrm{~Hz}$.

\section{8) Criterion 8: Impedance/Buffering}

A typical example, analog accelerometer performance with PIC \& AVR microcontroller requires to have output impedance under $10 \mathrm{KOhm}$ in order to properly perform A/D. Particularly, Analog Device accelerometer has output impedance of $32 \mathrm{KOhm}$. Hence, it needs a low input offset rail to rail OP amp as a buffer to lower the output impedance. Since requirement analysis has limited accelerometer must be digital, therefore, criterion 8 does not in concern.

\section{9) Criterion 9: Voltage supply}

Voltage supply is another important issue in measurement life span. Luckily, this is not the concern of the analog sensor due to the cabling connection. The cable is capable to provide the power source. Unlike the digital sensor, the common way to deliver the power is to add the battery pack. By selecting lowest power consumption of accelerometer to prevent frequently renews battery pack. Again, refers to provide data sheet, the comparison of supply voltage and current consumption for each type of accelerometer can be constructed.

TABLE V. POWER CONSUMPTION OF EACH ACCELEROMETER.

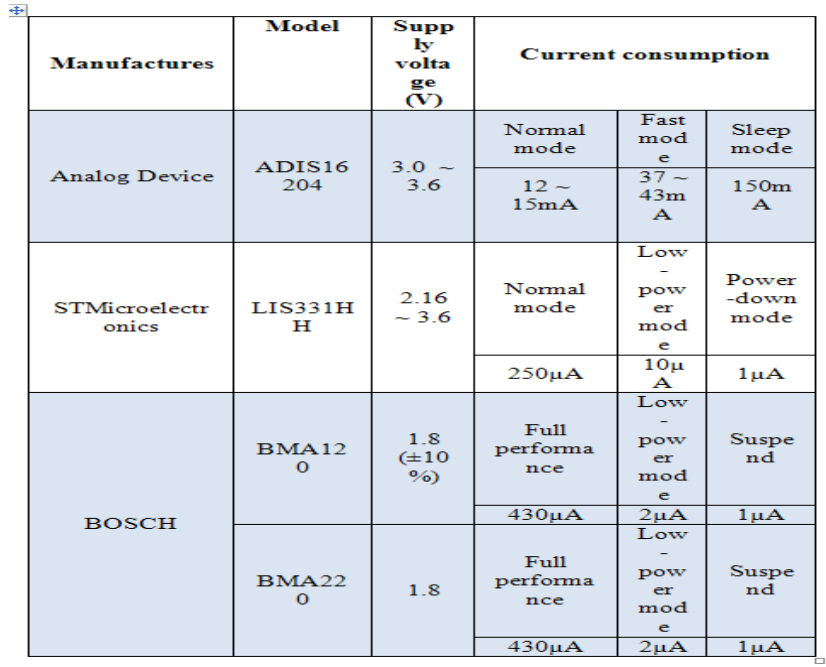

10) Criterion 10: Temprature Range

Temperature has directly effect on particular type of accelerometer technology. For instance, PR is sense to temperature and it needs to compensation for output. On the other hand, VC is insensitive to temperature as table 19 , appendices A.3, expresses the characteristic of $\mathrm{VC}$ accelerometer.

\begin{tabular}{|l|l|l|}
\hline Manufactures & Model & Temperature \\
\hline Analog Device & ADIS16204 & $\begin{array}{l}-40^{\circ} \mathrm{C} \text { to } \\
+125^{\circ} \mathrm{C}\end{array}$ \\
\hline STMicroelectronics & LIS331 $\mathrm{HH}$ & $\begin{array}{l}-40^{\circ} \mathrm{C} \text { to } \\
+85^{\circ} \mathrm{C}\end{array}$ \\
\hline \multirow{3}{*}{ BOSCH } & BMA120 & $-20^{\circ} \mathrm{C}$ to $+70^{\circ} \mathrm{C}$ \\
\cline { 2 - 3 } & BMA220 & $-20^{\circ} \mathrm{C}$ to $+70^{\circ} \mathrm{C}$ \\
\hline
\end{tabular}

TABLE VI. TABLE OF TEMPERATURE COMPARISON FOR EACH ACCELEROMETER.

Although table VI indicates ADIS16204 has wide temperature range that other, the PE type accelerometer has temperature drift about $2 \mathrm{~Hz}$. Hence, LIS331HH is the better option for WiVi sensor.

\section{1) Criterion 11: Linearity}

The difference between the actual transfer function and best straight line within particular operating range called linearity. According to datasheet, ADIS16204 has nonlinearity about $0.2 \%$ of the full-scale output, whereas, BMA series has $\pm 2 \%$ of the full-scale output. However, 
LIS331HH has zero percent nonlinearity in full-scale output.

\section{2) Criterion 12: communication port}

The most popular communication conduit of accelerometer is SPI, I2C or both coexisting. Moreover, clock frequency of data transmission is different between both communication interfaces. Table VII, below, gives the different clock speed between both communication interfaces for each accelerometer.

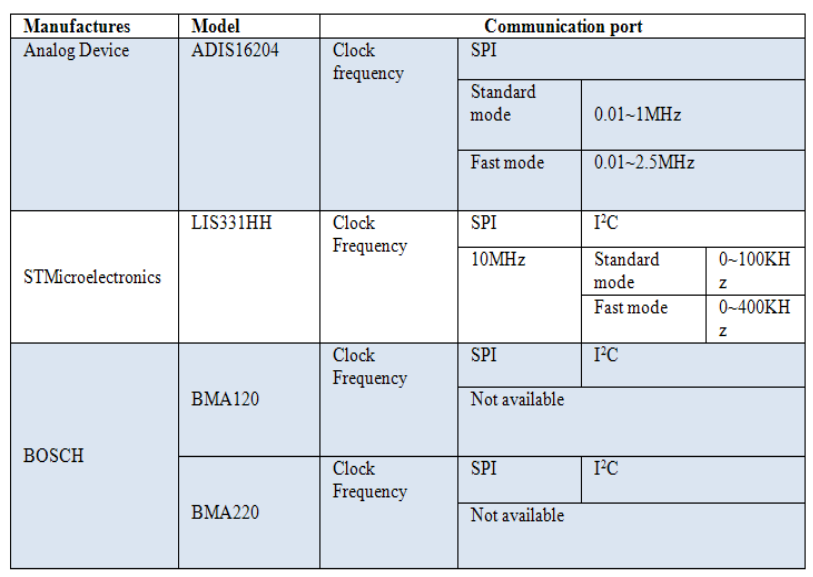

TABLE VII. CLOCK SPEED OF TWO COMMUNICATION INTERFACE FOR EACH ACCELEROMETER.

LIS331HH has both communication interfaces with $10 \mathrm{MHz}$ clock frequency in SPI and $400 \mathrm{KHz}$ in fast mode of I2C , whereas, ADIS16204 is not preferred due to unique communication interface, SPI, with $2.5 \mathrm{MHz}$ at fast mode. Obviously, LIS331HH has flexibility of communication interface than others.

\section{3) Criterion 13: Reliability}

Reliability of accelerometer is highly dependent on the absolute maximum ratings for some parameters such as operating temperature range, supply voltage, pins supply voltage, shock resistance etc. For example, LIS331HH has shock survivability about $10000 \mathrm{~g}$ for 0.1 milliseconds and $3000 \mathrm{~g}$ for 0.5 milliseconds either unpowered or powered. ADIS16204 has shock survivability about $4000 \mathrm{~g}$ for 0.5 milliseconds for any axis either unpowered or powered.

Therefore, LIS331HH has higher survivability than ADIS16204.

\section{4) Criterion 14: Cost}

The cost of accelerometer does not a major concern in the overall project since the revolution of technology. The price of accelerometer from varies of manufacture has not big difference. Therefore, it can be considered as a second last two of criterion.

15) Criterion 15: Size

Since size is dependent on the application and it can be microminiaturization in later design production stage. Most digital sensor manufactures have applied the MEMs technology as mention previously, the size of digital accelerometer is much smaller.

\section{B. Selected accelerometer}

Based on selection criteria in above section, LIS331HH has more criterions with better ranking in compare to other manufactures. Thus, LIS331HH has selected. The picture blow illustrates the dimension of LIS331HH accelerometer. It is a $3 \mathrm{mmX} 3 \mathrm{mmX} 1 \mathrm{~mm}$ with 16 pins accelerometer.

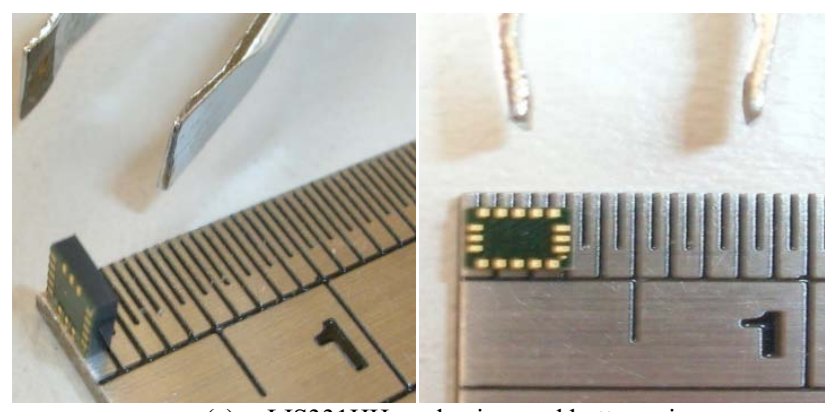

(a) LIS331HH angle view and bottom view

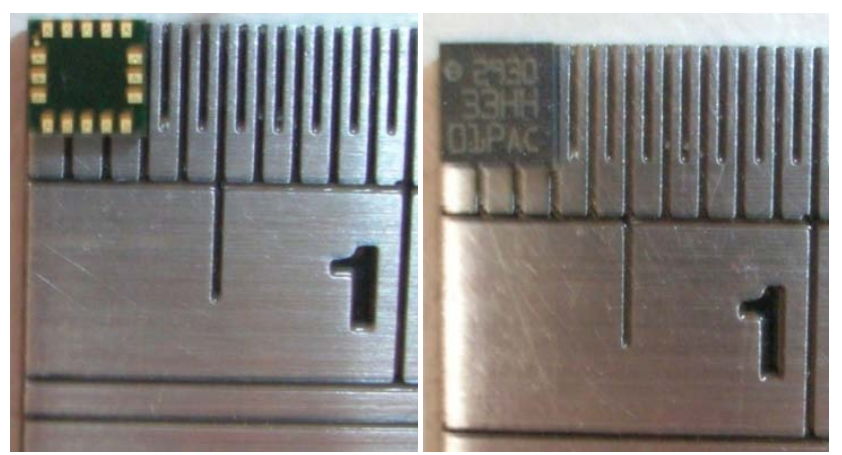

(b) LIS331HH close bottom view and top view.

Figure 2. LIS331HH hardware component.

\section{Wireless communication}

Wireless communication is known as a coreless data transmission from one point to another. The application of wireless communication is now associated with our daily lives, a simple example is the mobile phone. Moreover, middle part of electromagnetic spectrum is largely used by modern wireless communication systems [2]. The middle part of electromagnetic spectrum is divided into several frequency ranges as shown in the following table.

TABLE VIII. : FREQUENCY BAND OF DIFFERENT WIRELESS COMMUNICATION SYSTEM.

\begin{tabular}{|c|c|}
\hline $\begin{array}{c}\text { Type of wireless communication } \\
\text { system }\end{array}$ & Frequency band \\
\hline Radio frequencies & $10 \mathrm{kHz}$ to $1 \mathrm{GHz}$ \\
\hline Microwave frequencies & $\begin{array}{c}1 \mathrm{GHz} \text { to } 500 \\
\mathrm{GHz}\end{array}$ \\
\hline Visible and infrared frequencies & $500 \mathrm{GHz}$ to $1 \mathrm{THz}$ \\
\hline
\end{tabular}


Halit states that wireless techniques application requires greater bandwidth [2]. Nevertheless, Stig Petersen, Simon Carlsen and Amund Skavhaug states that contribution of wireless communication can enormously reduced installation and operation cost [6]. Meanwhile, it allows remote and hostile installations. This practically an approach is called cost-efficiency in device communication aspects. Recently, the application of wireless technology in oil, gas and resources industries has significant improve the operation to some extent. Akhondi states that wireless communication is capable in contributing low operation cost and eliminating the need for core installation [7].

Amount those advantages above, wireless communication is likely to adopt into WiVi sensor. According to spread spectrum IEEE 802 standard, it regulated wireless network usage for popularity application as Internet, portable devices and laptop computers. Table 11 indicates IEEE 802 wireless network standards for different function.

TABLE IX. TABLE OF IEEE 802 WIRELESS NETWORK STANDARDS [2].

\begin{tabular}{|c|c|c|}
\hline Standard & Name & Function \\
\hline 802.1 & Internetworking & $\begin{array}{l}\text { Routing, bridging, and Internet } \\
\text { work communication }\end{array}$ \\
\hline 802.2 & Logical link control & $\begin{array}{c}\text { Error control and flow control } \\
\text { over data frames }\end{array}$ \\
\hline 802.3 & Ethernet LAN & $\begin{array}{c}\text { Forms of Ethernet media and } \\
\text { interfaces }\end{array}$ \\
\hline 802.4 & Token bus LAN & $\begin{array}{c}\text { Forms of Token bus media and } \\
\text { interfaces }\end{array}$ \\
\hline 802.5 & Token ring LAN & $\begin{array}{c}\text { Forms of Token ring media and } \\
\text { interfaces }\end{array}$ \\
\hline 802.6 & $\begin{array}{c}\text { Metropolitan area } \\
\text { networks }\end{array}$ & $\begin{array}{l}\text { MAN technologies, addressing } \\
\text { and services }\end{array}$ \\
\hline 802.7 & $\begin{array}{l}\text { Broadband Advisory } \\
\text { Group }\end{array}$ & $\begin{array}{c}\text { Broadband networking media, } \\
\text { interfaces, equipment }\end{array}$ \\
\hline 802.8 & $\begin{array}{l}\text { Fiber-optic Advisory } \\
\text { group }\end{array}$ & $\begin{array}{c}\text { Fiber-optic media, network } \\
\text { types, technologies }\end{array}$ \\
\hline 802.9 & Integrated networks & $\begin{array}{l}\text { Integration of voice and data } \\
\text { traffic in a network medium }\end{array}$ \\
\hline 802.10 & Network security & $\begin{array}{c}\text { Network access control, } \\
\text { encryption, certification, other } \\
\text { security }\end{array}$ \\
\hline 802.11 & Wireless networks & $\begin{array}{c}\text { Wireless networks, frequency } \\
\text { usage }\end{array}$ \\
\hline 802.12 & High-speed networking & $\begin{array}{c}\text { Variety of } 100 \text { Mbps-plus } \\
\text { technologies }\end{array}$ \\
\hline 802.13 & Unused & \\
\hline 802.14 & Defunct working group & Data transfer over cable TV \\
\hline 802.15 & $\begin{array}{c}\text { Wireless personal area } \\
\text { networks }\end{array}$ & $\begin{array}{c}\text { Emerging standards for wireless } \\
\text { PANs }\end{array}$ \\
\hline 802.16 & $\begin{array}{l}\text { Wireless metropolitan } \\
\text { area networks }\end{array}$ & Wireless MANs \\
\hline 802.17 & Resilient packet ring & $\begin{array}{l}\text { Very high speed ring-based } \\
\text { LANs and MANs }\end{array}$ \\
\hline 802.18 & $\begin{array}{l}\text { Wireless Advisory } \\
\text { Group }\end{array}$ & Radio-based wireless standards \\
\hline
\end{tabular}

Table IX indicates 802.11 is particularly classified for wireless networks and it is commonly known as Wi-Fi. Since there are variety of wireless communication system, table $\mathrm{X}$ gives the comparison of advantages and disadvantages of systems. According to the Bose's lecture two [3], there are four major types of wireless communication. There are indicates at table below.

TABLE X. TABLE OF COMPARISON FOR VARIES TYPE OF WIRELESS COMMUNICATION

\begin{tabular}{|c|c|c|c|}
\hline $\begin{array}{l}\text { Type of wireless } \\
\text { comnunicatioul }\end{array}$ & Adrantages & Disadvantages & Description \\
\hline Radio communication & $\begin{array}{l}\text {-easy to generate } \\
\text {-loug disirace travelling } \\
\text {-penetrate building }\end{array}$ & $\begin{array}{l}\text { - freçuency depend } \\
\text {-low bandwidh } \\
\text {-license required by } \\
\text { govemment }\end{array}$ & $\begin{array}{l}\text { The earliest and most } \\
\text { popular wireless } \\
\text { communicationand still } \\
\text { existtoday. }\end{array}$ \\
\hline Microwave & $\begin{array}{l}\text { - long distance communication } \\
\text {-high signal ratio } \\
\text {-inexpensive }\end{array}$ & $\begin{array}{l}\text {-lowpenetration ability } \\
\text {-wieather and frequancy } \\
\text { dependent }\end{array}$ & $\begin{array}{l}\text { Point to point transmission } \\
\text { through tall tower and } \\
\text { anntna. }\end{array}$ \\
\hline $\begin{array}{l}\text { Infrared and millimeter } \\
\text { waves }\end{array}$ & -short range communication & $\begin{array}{l}\text { - Uneble to pass } \\
\text { through solid objects } \\
\text {-Indoor wireless LANis } \\
\text { only }\end{array}$ & $10 \mathrm{~m}$ transmissionrange \\
\hline Lightwave Transmission & $\begin{array}{l}\text {-easily install } \\
\text { - In nead for license }\end{array}$ & $\begin{array}{l}\text { - Tneble to penetrate } \\
\text { rainor thick fog } \\
\text { - Turnulent ait can } \\
\text { diverted lightwave }\end{array}$ & \\
\hline
\end{tabular}

Clearly, radio frequency is the earliest and most popular type of wireless communication. Importantly, radio communication enables to penetrate through building, whereas, others depend on the transmission tower or only used indoor WLAN application. Table 14 indicates the transmission distance for varies radio transmissions. Obviously, WLANs is the better option for WiVi sensor. The transmission range for different radio transmission is given in the following table 14. It indicates the WLANs has transmission distance less than $1 \mathrm{Km}$. For the purpose of monitoring system is sufficient.

TABLE XI. TYPE OF RADIO FREQUENCY AND TRANSMISSION DISTANCE

\begin{tabular}{|l|l|}
\hline $\begin{array}{l}\text { Type of radio } \\
\text { transmission }\end{array}$ & $\begin{array}{l}\text { Transmission } \\
\text { distance }\end{array}$ \\
\hline Infrared & $<10 \mathrm{~m}$ \\
\hline Bluetooth & $<100 \mathrm{~m}$ \\
\hline WLANs & $<1 \mathrm{~km}$ \\
\hline $\begin{array}{l}\text { Mobile } \\
\text { Technology } \\
\text { WLL }\end{array}$ & $<50 \mathrm{~km}$ \\
\hline $\begin{array}{l}\text { FM radio } \\
\text { frequency }\end{array}$ & $<100 \mathrm{~km}$ \\
\hline $\begin{array}{l}\text { MW radio } \\
\text { frequency }\end{array}$ & $<300 \mathrm{~km}$ \\
\hline $\begin{array}{l}\text { SW radio } \\
\text { frequency }\end{array}$ & $<500 \mathrm{~km}$ \\
\hline Satellite Links & $<1000 \mathrm{~km}$ \\
\hline
\end{tabular}

Table XI gives the specification of IEEE 802.11 standard. The wireless LANs is what designer looking for in order to 
ease utilization measurement instrument communication. Wireless modules research whitepaper (Wireless module research n.d.) states that $892.11(\mathrm{~b}, \mathrm{~g}, \mathrm{n})$ are common widely used from household.

\section{FUTURE WORK}

\section{A. Future Wireless Option}

The future of wireless $802.11 \mathrm{n}$ has been released in full specification into the market. The connection between the wireless dongle and the microcontroller is using a USARTs connection which is very generic.

Therefore, this design allows future wireless module replacement in ease. This design is not limited to wireless 802.11 frequency communications. There are other wireless option that uses the same USARTs connection such as, Bluetooth, 4G, 3G, ZigBee, etc.

\section{B. Custom designed microcontroller}

If the prototype proves successful, it is possible to request custom microcontroller that is specifically designed to the needs of this device. This will greatly reduce the power consumption and allow the device to focus on what it is designed to do.

\section{Power Source}

The current power source is based on battery packs supplies. The future preference would be to acquire the power from the vibration itself. This is made possible by turning the kinetic energy generated by the vibration into electrical energy. However, the vibration can only generate limited amount of energy. Thus, the device must run on circumscribed power source.

\section{Coalition Device Network}

If more than one same device in the network is place separately on a single machine. The data of these devices can be combined to simulate the machine. There are infinite potential in understanding the vibration profile of this machine [8][9][10][11].

\section{CONCLUSION}

In this paper has been tired to research and consider all criteria for hardware selection to find the best hardware which suitable and applicable for our project.

\section{REFERENCES}

[1] Accelerometer selection based on applications. 1999 http://www.hightech-pr.com/endevco/2006_08/2006_08_f4.pdf (accessed October 10, 2009).

[2] Eren, H. 2006. Wireless Sensors and instruments. NW: Taylor \& Francis.FastFourierTransform.1999.

http://mathworld.wolfram.com/FastFourierTransform.html (accessed August 22, 2009).

[3] Bose, R. 2008. Lecture 2: Types of wireless communication. PowerPoint slides. Retrieved from Indian Institute of Technology Delihi Web site: http://www.youtube.com/watch?v=QHDxbbc1GWs (accessed November 25, 2009).

[4] Toliyat, H. and Kliman, G. 2004. Handbook of electric motors. http://books.google.com.au/books?id=4-

Kkj53fWTIC\&printsec $=$ frontcover $\# \mathrm{v}=$ onepage $\& \mathrm{q}=10 \% 20 \mathrm{~Hz} \& \mathrm{f}=$ fals e (accessed July 10, 2010).

[5] Wilson, J. 2005. Sensor technology handbook. MA: Newnes.

Wireless Module Research. n.d. http://www.infotekintl.com/WirelessResearch.pdf (accessed November 26, 2009).

[6] Peterson, S., Carlsen, S. and Skavhaug, A. n.d. Layered software challenge of wireless technology in the oil \& gas industry. http://ieeexplore.ieee.org/Xplore/login.jsp?url=http\%3A\%2F\%2Fieee xplore.ieee.org\%2Fiel5\%2F4483171\%2F4483172\%2F04483188.pdf $\% 3$ Farnumber\%3D4483188\&authDecision=-203(accessed November 24, 2009).

[7] Akhondi, M., Talevski, A., Carlsen, S. and Petersen, S. 2010 Applications of wireless sensor networks for oil, gas and resources industries. CS Digital Library journal. http://www.computer.org/portal/web/csdl/doi/10.1109/AINA.2010.18 (accessed December 7, 2010).

[8] A micromachined thermal accelerometer. Image. 2001. http://archives.sensorsmag.com/articles/0601/98/index.htm (accessed July 20, 2009).

[9] Technology. 2008. http://www.silicondesigns.com/tech.html (accessed July 19, 2009).

[10] Tiny accelerometer. 2001. http://archives.sensorsmag.com/articles/0201/20/index.htm (accessed July 20, 2009).

[11] Trends in accelerometer design for military and aerospace $\begin{array}{ll}\text { application. } & \text { Image. }\end{array}$ http://archives.sensorsmag.com/articles/0399/0399_44/index.htm. 